ADDIN, Volume 11, Number 2, August 2017

\title{
DEVELOPING AND TESTING THE CONSTRUCT VALIDITY INSTRUMENT OF TAZKIYYATUN NAFS
}

\section{Rijal Firdaos}

State Islamic University of Raden Intan Lampung, Indonesia rijalfirdaos@radenintan.ac.id

\section{Abstract}

This research aims to develop and test the construct validity of the Tazkiyyatun Nafs instrument at the Tarbiyah and Teacher Training Faculty of UIN Raden Intan Lampung. The Population of this research was the students of Tarbiyah and Teacher Training Faculty that consisted of 150 students. The method employed in this research was survey technique by using Likert Scale parameter. The result of the empirical research states that 37 items of the Tarkiyyatun Nafs instrument are spread out into five dimensions. The result of construct validity by using factor analysis proved that several numbers of items that have been estimated are 37 indicators with the value of $>0.30$, out of 39 items, assuming that all items are estimated in accordance with the theory that have been constructed. The two other indicators are $<0.30$ which then eliminated. The two items that were eliminated are item A4 on the Taubid dimension, and point A11 on the shalat dimension. The implications of this research are expected can contribute to the progress of Islamic civilization, especially in relation 
to scientific integration by integrating Islamic sciences as its subject, and exact science as its methodology.

Keywords: Developing, Construct Validity, Tazkizyatun Nafs.

\section{Abstrak}

MENGEMBANGKAN DAN MENGUJI INSTRUMEN VALIDITAS KONSTRUKSI TAZKIYATUN NAFS. Penelitian ini bertujuan untuk mengembangakan dan menguji validitas konstruk instrumen Tąkiyyatun Nafs mahasiswa Fakultas Tarbiyah UIN Raden Intan Lampung. Populasi dalam penelitian ini adalab mahasiswa Fakultas Tarbiyah berjumlah 150 orang. Metode dalam penelitian ini menggunakan teknik survey dengan menggunakan parameter Skala Likert. Hasil penelitian secara empiris menyatakan babwa 37 item instrumen Tazkiyyatun Nafs tersebar ke dalam lima dimensi. Hasil validitas konstruk dengan menggunakan analisis faktor, telah membuktikan bahwa sejumlah butir yang telah berhasil diestimasi sebanyak 37 indikator yang berada >0,30, dari jumlah 39 butir, dengan asumsi babwa semua item yang diestimasikan sesuai dengan teori yang dibangun. Sementara dua indikator yang berada $<0,30$ kemudian dieliminasi atau gugur. Adapun dua butir yang gugur tersebut adalah butir $A 4$ pada dimensi taubid, dan butir $A$ 11 pada dimensi shalat. Implikasi penelitian ini diharapkan dapat memberikan kontribusi bagi kemajuan peradaban Islam, terutama dalam bubungannya dengan integrasi keilmuan, dengan cara memadukan antara ilmu-ilmu keislaman sebagai subjeknya, dan ilmu eksak sebagai metodologinya.

Kata Kunci: Pengembangan, Validitas Konstruk, Tarkiyyatun Nafs.

\section{A. Introduction}

Education holds an important role in human life. Education has been acknowledged as a force that can assist the people to attain advancement and magnificence of civilization. The advancement of knowledge and technology 
can prove that the role of education is vital for many aspects of human life, such as the aspect of economy, politics, and culture. However, these advances do not always present positive impacts on human life, especially in the betterment of a person's religious education. Education is also an absolute necessity that must be fulfilled throughout life. Without education, it is absolutely impossible for a group of people to live with the mutual objective to advance, prosper and contend according to the concept of their worldview. ${ }^{1}$

Education is like an experiment that never ends as long as human exists in this world. It is said that, because education is a part of the culture and human civilization that grows endlessly. This is in line with the human nature that holds potential to be creative and innovative in all of the aspects of life $^{2}$. In the family environment, parents are the first and primary educators in terms of cultivating faith for their children. They are called the principal educators for their enormous influence, and also because they are the first to educate their children. ${ }^{3}$ As Zakiah Daradjat states that parents are the first and primary educators for their children, because the children receive their first education from them. ${ }^{4}$

This is the role of education as one of the process of personality transformation becomes an important point in human life. It has become a way and media to develop all human potential. The purpose of education, especially Islamic education is to develop human potential that tends to

\footnotetext{
${ }^{1}$ Fuad Ihsan, Dasar-dasar Kependidikan (Jakarta: Rineka Cipta, 2008), 2.

${ }^{2}$ Hasbullah, Dasar-Dasar Ilmu Pendidikan (Jakarta: Raja Grafindo Persada, 2005), 9.

${ }^{3}$ Ahmad Tafsir, Pendidikan Agama Dalam Keluarga (Bandung: Remaja Rosdakarya, 2002), 8.

${ }^{4}$ Zakiyah Drazat, Ilmu Pendidikan Islam (Jakarta: Bumi Aksara, Jakarta: 2009), 35 .
} 
be positive so that it is expected to form a good personality. Therefore, it is reasonable if Darajat, as quoted by Shaleh, states that religion is one of the integrated elements in the process of psychological healing. ${ }^{5}$

Good character arises from good soul or known as a calm soul (nafs al-muthmainnah), the soul that is always calm with piety and closeness to God and submits to the provisions of God. In the process of reaching that perfect and calmness level of soul, the soul purification (tazkiyyatun nafs) is needed. Al Ghazali as quoted by Shalihin states that good manners will always come from a good soul. So the process of soul purification is an indirect process of emptying the soul from bad morality. ${ }^{6}$

The occurrence of moral decadence among teenagers, as Firdaos (2016) views allegedly because of the poor standard of the view of one's soul on how important to bring out the heart in every activity. In fact, the criminal case that is now spreading, does not only apply to the laymen. As a member of educated society, the college students have been the subject of such crimes. It could be brawl between colleges, sexual offenses, murder, even terrorism, which in the last decade has become the talk in Indonesia. ${ }^{7}$ Including, the murder committed by one of the students against a lecturer at one of the universities in North Sumatra recently shows that the criminal case has spread to the intellectual community, which is in fact as a national asset.

\footnotetext{
${ }^{5}$ Moh. Shaleh, Bertobat Sambil Berobat (Jakarta: Mizan Publika, 2008), 38 .

${ }^{6}$ M. Shalihin, Tazkiyatun Nafs dalam Perspektif Tasawuf Al-Ghazali (Bandung: Pustaka Setia, 2000), 107.

${ }^{7}$ Rijal Firdaos, "Studi Analisis Faktor Konfimatori terhadap Dimensi Sikap Keberagamaan Mahasiswa", Jurnal Inferensi, Vol. 10, No. 2, December 2016, 359-380.
} 
In fact, religion has a significant contribution to the development of a one's psychological/spiritual needs. The dimension of the soul in human life is very influential in fostering faith, islamic and good behavior for a good Muslim. The importance of one's spiritual dimension relate to God vertically and relate with humans horizontally, is the principal basis which must be established by istikamah. The soul of a person during that resides in the body will require spiritual consumption in order to grow healthy and independent. The education of a Muslim will not succeed to the fullest if it cannot cultivate his sense of soul to the level of holiness, glory and nobility. To reach the stage of nobility, it must begin from the first stage of soul purification. This stages in Arabic are called tazkiyatun nafs. ${ }^{8}$ (Purification of the soul).

Tazkiyah is derived from Zakaa Yazku-Zakaa \& Zakatan which means Naama (grow) and Zaada (Increase). Zakaa can also mean Solaha (good) and it also means Barokah (abundant goodness), besides it also means Thaharoh or clean. ${ }^{9}$ The word Tazkiyah from the word Zaka is given extra kaf, so it becomes Zakka-Yuzakki-Tazkiyatan which means to grow, to develop, to mend, to clean, to purify and to be good and better. The word Zakka-Tazkiyatan in various forms has been mentioned in the Qur'an repeatedly, even up to 20 times, 9 times in the verses of Makkiyah and 11 times in the verses of Madaniyah.

${ }^{8}$ The word nafs is a word that has many meanings (lafadz musytarak) and should be understood in accordance with its use. Among the existing terminology, the meaning of the nafs includes: a) The soul of something having existence and essence, the nafs in this context means body and spirit, b) The life that triggers the existence of life, if life is lost, then death will come, c) Self or a place where conscience resides. Nafs in this sense is always attributed to God and also to man, d) A nature in man in the sense of senses he left behind when he fell asleep. Muhammad Izzadudin Taufiq, Complete Guide and Practical Psychology of Islam, (Jakarta: Gema Insani, 2006), 70-72.

${ }^{9}$ Jumhur Misri al-Arabi, Mu'jam al-Wasith (Mesir: Maktabah as-Syuruk ad-Dauliyyah, 2004), 396. 
The word $A n$-Nafs can mean the spirit / life / soul, as In the verse "Get Your Ruh out", it can mean breath, which is air that comes out and into the human body, through the mouth or nose. ${ }^{10}$

In the encyclopedia of Islam, the Nafs is considered as an organ, a spiritual aspect of a man that possesses the greatest influence among the other spiritual aspects that instruct the physical organ to perform an action ${ }^{11}$ In the dictionary of the tasawuf, the word nafs has several meanings, firstly, the nafs is the self in the physical nafs arrangement is not separated two dimensions. Second, the meaning of the nafs is consciousness, humanity or "I internal". It means, all sorts of anxiety, calmness, pain, and so on are for one to perceive, and not necessarily could be expressed physically. Other people can only imagine what "I internal" feels. Third, the meaning of nafs that can be interpreted with species (same kind). Fourth, is defined as the will, the want, and the passions. In other words, the nafs is the driving force that evokes activity within the living beings and drives the behavior and directs it toward a goal or a variety of goals. ${ }^{12}$

In short, purifying the soul and heart (tazkiyatun nafs) is purifying oneself from the act of syirik and derivatives such as the need to be praised, arrogance, and other disgraceful traits and then internalize the values of oneness of god (taubid) and its positive qualities such as sincere, patient, gratitude, fear and Hope to Allah (khauf and raja), reliance in god (tawakal), god's approval (rida) and so forth. With this process of taqkiyatun nafs, a Muslim can behave according to

${ }^{10}$ Al-Mufradat Fii Qoribil Qur'an, 501.

${ }^{11}$ Kafrawi Ridwan, Ensiklopedi Islam (Jakarta: Ichtiar Baru, 1994), 342.

12 Totok Jumantoro, Kamus Ilmu Taswuf (Jakarta: Amzah, 2005), 159. 
the names of Allah in his capacity as a servant of god, based on sincerity to Him and follow the Sunnah of His Apostle. ${ }^{13}$

Al-Ghazali defines the soul as a substance (jaubar) that stands by itself and is not a condition or accident so that it is there on itself. The emergence of such strength begins with the will and then becomes action. ${ }^{14}$ Nafs is also considered as the last soul or the soul given by Allah SWT, or the thing that is deduced into the human body in order to make it alive, revive the heart, the mind, the senses, and to move all of the elements and organs of the body (jasadiyab) in order to interact with the environment on the surface of this earth.

Based on the types, al-Jalili quoted by al-Ghazali, divides the soul into five categories, namely: Nafs hayawaniyah (soul of bestiality), a soul that passively compliant to natural impulses, Nafs' ammarah (ruling soul), the soul that takes pleasure in lust (sybwat), regardless of the command and prohibition of God, Nafs mulhamah (soul that acquires knowledge), the soul that is guided by God to do good deed, Nafs lawwamah (soul that regrets), that is an unstable soul in its principles. ${ }^{15}$

Based on the explanations, it can be concluded that tazkiyatun nafs is essentially a process of cleansing the soul and heart from various sins and disgraceful traits that pollute them, and further improving the quality of the soul and the heart by developing praiseworthy qualities that Allah blesses and its positive potentials with mujahadah, worshiping and doing other good deeds, so that the heart and soul become clean and good, which then can make someone possesses good and praiseworthy nature and behavior.

${ }^{13}$ Said Hawa, al-Mustakblas fi Tazkiyatil Anfus: Nazariyyah Mutakamilah fi Tazkiyatin-Nufus (Kairo: Darus Salam, 2005), 153.

${ }_{14}$ Al-Ghazali, Tangga bagi Para Hamba yang Hendak Merambah Jalan Allah, transl. Fathur Rahman, (Yogyakarta: Mitra Pustaka, 2005), 65.

${ }^{15}$ Ibid., 60-61. 
A valid tarkiyatun nafs instrument is one of the media to measure one's personality, which is related to the sanctity of his soul, the clarity of his heart, and from the emergence of diseases of the dirty heart. In the context of collecting information, instrument plays an important role in determining the quality of a study. ${ }^{16}$ Instruments are tools used by anyone, especially by researchers to collect data through measurement. This method is done to obtain the objective and necessary data to produce objective research conclusions. ${ }^{17}$ According to Colton and Covert, Instrument is a mechanism for measuring phenomena, which is used to gather and record information for assessment, decision making, and ultimately understanding. ${ }^{18}$ Instruments such as questionnaires are one of the means used to obtain factual information, to observe, or to assess an attitude and opinion. The science of measurement is a branch of applied statistics that aims to build the basics of a better test development so that an optimally functioning, valid, and reliable test can be produced. The basics of test development are built on mathematical models that are continuously tested of their feasibility by psychometric science. ${ }^{19}$

Operationally, measurement is a comparative procedure between the attributes that would be measured with their measuring instrument. Among the measurement characteristics are; first, is a comparison between the measured attributes

${ }^{16}$ Rijal Firdaos, "Metode Pengembangan Instrumen Pengukur Kecerdasan Spiritual Mahasiswa”, Jurnal Edukasia, Vol. 11, No. 2, August 2016, 377-398. 2010), 183

${ }^{17}$ Purwanto, Metodologi Penelitian Kuantitatif (Yogyakarta: Pustaka Pelajar,

${ }^{18}$ David Colton and Robert W. Covert, Designing and Constructing Instruments for Social Research and Evaluation, (San Francisco: Jossey-Basse, 2007), 5.

${ }^{19}$ Saifuddin Azwar, Dasar-Dasar Psikometri (Yogyakarta: Pustaka Pelajar, 2005), 3. 
with their measuring instrument; second, the result is expressed quantitatively, and third, the result is descriptive. ${ }^{20}$ These three characteristics become an integral part in every measurement activity.

The science of measurement falls into the category of quantitative research. The strength of this approach is its ability to provide explicit information obtained from a particular study. ${ }^{21}$ In addition, quantitative research techniques are also often used to design how to disclose a theory, questioning the reliability and validity in a system of measurements toward phenomena to be studied. ${ }^{22}$

Thus, that measurement is an activity to detect an instrumentation (measuring instrument) in order to achieve the relevant degree in accordance with applicable rules, including validity, reliability, and readability. These three qualifications must be possessed in the concept of instrument development. Because, developing the instrument is one of the products development research that aims to produce a standard instrument of a concept of variables that are constructed based on relevant theories and constructs.

The Tazkiyyatun Nafs variable is a latent variable that cannot be observed directly unless through testing construct approach. However, constructs have a theoretical linkage between each other. ${ }^{23}$ Testing of construct validity is an ongoing process in line with the development of the concept of trait being measured. Although the test of construct validity usually requires more complex statistical analysis techniques than the techniques employed in other empirical

${ }^{20}$ Ibid., 4.

${ }^{21}$ Paul M. Camic, Qualitative Research in Psychology Expanding Perspective and Design (Washington, DC: American Psychology Association, 2003), 42.

${ }^{22}$ Ibid.

${ }^{23}$ Donna Harrington, Confirmatory Factor Analysis (New York: Oxford University Press, 2009), 5. 
validity tests, the result of construct validity is not expressed in terms of a validity coefficient.

Validity is a criterion or indicator to determine the extent to which an instrument should be measured. ${ }^{24}$ Validity also indicates the extent to which a test is considered good in accordance with the measurement design. ${ }^{25}$ Validity in the context of quantitative research is certainly different from validity in a qualitative approach. While construct validity refers to the extent to which an instrument is able to measure the terms contained in the material to be measured. ${ }^{26}$ The construct validity is determined by the accuracy and precision of the measurement. The procedures of construct validity test emerge from the computational inter-correlation between various tests results and then followed by further analysis of the correlation matrix obtained, through various methods. ${ }^{27}$

Magnusson as quoted by Saifuddin explains that if we want to assess the apparent nature of aggressiveness, we will do so after observing the behavior of the target for some time. ${ }^{28}$ Usually, a rating of such behavior becomes a valid indicator of the presence or absence of aggressiveness. However, if we want to express or measure the existence of a latent aggressiveness (which has not yet appeared to manifest in behavior) then we do so through a projective test, not through observation.

According to Sudjana, the validity of the construct is concerned with the ability of the assessment tool to measure

${ }^{24}$ C.R. Kothari, Research Methodology (New Delhi: New Age International Publisher, 2004), 74.

${ }^{25}$ Sharon E. Robinson Kurpius, Testing and Measurement (California: SAGE Publication, 2006), 141.

${ }^{26}$ Uno, Research, 140.

${ }^{27}$ Saifuddin Azwar, Reliabilitas dan Validitas (Yogyakarta: Pustaka Pelajar, 2008), 132

${ }^{28}$ Ibid., 11. 
the meanings contained in the material that is measured. The notions contained in the concepts of ability, interest, attitude in various areas of study must be clear of what it intends to measure. The concepts are still abstract; it requires a more specific elaboration so that it can be easily measured. ${ }^{29}$ According to Suryabrata the validity of the construct (construct validity) questioning the extent to which the score of measurement results with an instrument reflects the theoretical constructs that underlie the constructing process of the measurement. Two of the many approaches involved in construct validity testing consist of multitrait-multimethode approaches and confirmatory factor analysis approaches. ${ }^{30}$

The purpose of construct validity is to prove whether the measurements obtained through the test items are highly correlated with the theoretical constructs underlying the construction of such tests. Do the scores obtained support the theoretical concepts desired by the original purpose of measurement. ${ }^{31}$ Cronbach in Azwar states that to test the construct validity at least involves three steps, namely: (1) articulating a series of theoretical concepts and its intercorrelation; (2) developing a way to measure the hypothetical context being theorized; and (3) empirically testing the hypothetical relationship between constructs and their visible manifestations. ${ }^{32}$

Thus, the development of the instrument based on Firdaos's view (2016) is a development activity toward theoretical concept constructed in accordance with the

${ }^{29}$ Nana Sudjana, Penilaian Hasil Proses Belajar Mengajar (Bandung: Remaja Rosdakarya, 2005), 14.

${ }^{30}$ Sumadi Suryabrata, Alat Ukur Psikologis, (Yogyakarta: Andi, 2005), 42.

${ }^{31}$ Saifudin Azwar, Validitas dan Reliabilitas, (Yogyakarta: Pustaka Pelajar, 2012), 116.

${ }^{3}$ Ibid. 
construct with the aim to produce a standard instrument that refers to techniques that have been established by the experts gradually and proportionately. ${ }^{33}$ Instrument development requires strong theories to underlie a construct of the phenomenon to be measured to produce a good and relevant instrument. This study aims to develop and test the construct validity instrument of tarkiyatun nafs of the students of Tarbiyah and Teacher Training Faculty of UIN Raden Intan Lampung. In line with the mentioned objectives, the design of this study is product development techniques. ${ }^{34}$

\section{B. Discussion}

\section{Empirical Validity Testing}

Based on the study of various theories about tazkiyatun nafs, six dimensions are formulated with the following indicators: The dimension of taubid (oneness of god) with the following indicators: iman, Islam, and ihsan. Dimensions of salat (prayer) with the following indicators: knowing the importance of salat, obligatory salat, salat rawatib, and sunnab nawafil. Dimension of zakat and infak (almsgiving) with the following indicators: Know the importance of rakat, know the importance of infak, pay zakat, and fulfill infak. Fasting dimension with indicators; Knowing the importance of fasting, knowing the laws of fasting, performing the obligatory fasting, and carrying out the sunnah fasting. Dimension of reading the Qur'an with indicators; Know the importance of reading the Qur'an and able to read the Qur'an well. Dimensions of leaving things that are forbidden

${ }^{33}$ Rijal Firdaos, Desain Instrumen Pengukur Afektif (Lampung: AURA Publishing, 2016), 114.

${ }^{34}$ Rita C. Richey and James D. Klien, Design and Development Research: Methodes, Strategies, and Issues (New Jersey: Lawrence Erlbaum, 2007), 9. 
with indicators; Know the things that are forbidden and leave things that are forbidden.

\section{Dimension of Tauhid}

The validation test of taubid dimension with factor analysis approach was to assess which variables are considered adequate to be included in the next analysis. This test was done by entering all the variables to be tested. The logic of the test was that if a variable does have a tendency to group and form a factor, then the variable would have a fairly high correlation with other variables. The following is the result of SPSS calculation of each dimension.

The first stage of factor analysis was to assess which variables were considered adequate to be included in the next analysis. This test was done by entering all the variables to be tested. The logic of the test was that if a variable does have a tendency to group and form a factor, then the variable would have a fairly high correlation with other variables. Vice versa, variables with weak correlation with other variables tend not to group with certain factors.

The calculation of factor analysis was using SPSS for windows version 17.00. The calculation result of taubid dimension factor analysis obtained by KMO was: 0. 558 classified as moderate, with chi-square value $=27.493$ with significance ( $\operatorname{Sig}=0,025$ at $\mathrm{dk}: 15)$.

Table 1. The Result of KMO Measure Sampling Adequacy and Bartlett Test of Taubid Dimension

\begin{tabular}{cccc}
\hline \multirow{2}{*}{ KMO MSA } & \multicolumn{3}{c}{ Bartlett's Test of Sphericity } \\
\cline { 2 - 4 } & Approx. Chi-Square & df & Sig. \\
\hline 558 & 27.493 & 15 & 0.25 \\
\hline
\end{tabular}

The dimension of taubid consisted of 8 items, in which 6 items indicating greater value $(>0.5)$. While the other two items which were item A2 with MSA 0.459 and item A6 with 
MSA 0.498 must be eliminated because they were below 0.5 . The criteria of significance are: Sig. $>0.05$ then Ho is accepted. The value of Sig. $<0.05$ then Ho is rejected. The MSA (Measures of Sampling Adequacy) score ranges from 0 to 1 with the criteria: (a) MSA $=1$, the variables can be predicted without error by another variable. MSA $>0,05$, the variables can still be predicted and can be analyzed further. MSA $<0.5$, the variables cannot be predicted and cannot be analyzed further, or removed from other variables. Below is the result of the recapitulation of the MSA value which having the value above 0.05 in overall, with the assumption that all variables are adequate for further analysis.

After conducting the first step, which was to filter the number of variables to ensure that all the variables meet the requirements for analysis, then the main process of factor analysis was carried out, which was to extract the present sets of variables, so that one or more factors are formed.

The method in producing the factors (factor extraction) used the Principal Component Analysis methods are shown in the Communalities table as the result of extraction. The largest value in item 5 (A5) was: 0.594 approximately 59\% variance of variable item 5 can be explained by the factors formed. The smallest percentage was 0.336 in item 3 , or $33 \%$ variance of variable 3 can be explained by the factor formed. And so on for other variables, with the requirement of the greater the communalities of a variable, more closely related to the factors that are formed.

The results of the analysis of the overall variance which can be explained by the components formed with the value of eigenvalues greater than 1.00 where there were 2 factors with the eigenvalues greater than $(>)$ 1.00. One factor had the greatest eigenvalues which was factor one (1.509), which was then followed by a factor $2(1,087)$, so that the cumulative of 
the 2 factors was 43,260 variance. The first eigenvalues factor had the largest value which then served as the proof of the dominant factor in all the variables/items present.

The result of membership factor analysis by using Principal Component Analysis method with varimax with Kaiser Normalization rotation method, successfully formed two factors with each factor member of the following, by eliminating one item below the loading factor of $<0.30$ namely item 04 with Loading factor of $0,-646$.

Table 2. The Factor and Loading Factor

\begin{tabular}{cccc}
\hline Factor & Member & Loading Factor & Number \\
\hline 1 & A1 & 0.674 & 2 \\
& A2 & 0.538 & \\
& A4 & $\mathbf{0 . - 6 4 6}$ & \\
\hline 2 & A3 & 0.426 & 3 \\
& A5 & 0.605 & \\
& A6 & 0.650 & \\
\hline
\end{tabular}

The table shows that 5 items are constructed on the dimensions of taubid, after the factor analysis was conducted which then formed two factors, each factor was named as follows: The first factor with 2 items were named the factor of iman and islam, the second factor with 3 items were named ihsan.

\section{Dimension of Shalat}

The result of validity calculation by using factor analysis on the dimension of shalat (prayer), obtained KMO of: 0.660 classified as moderate, with value of chi-square $=$ 65.180 with significance ( $\operatorname{Sig}=0,000$ at $\mathrm{dk}$ : 15 ) that shows the value with significance level below 0.05 . it means that the correlation matrix formed was not the identity matrix so that all of the items variables in the analyzed religiosity instrument are adequate for further analysis. 
Table 3. The Result of KMO Measure Sampling Adequacy and Bartlett Test of the Dimension of Shalat

\begin{tabular}{cccc}
\hline \multirow{2}{*}{ KMO MSA } & \multicolumn{3}{c}{ Bartlett's Test of Sphericity } \\
\cline { 2 - 4 } & Approx. Chi-Square & df & Sig. \\
\hline 660 & 65.180 & 15 & 0.00 \\
\hline
\end{tabular}

There were 11 items in the dimension of shalat, where 9 items indicated that the values were greater than $(>0,5)$. While the other two items which were item A10 dan A11 must be eliminated since their value below 0.5 . the criteria of significance: the value of Sig. $>0,05$ means Ho is accepted. The value of Sig. $<0,05$ means $H o$ is rejected. The value of MSA (Measeure of Sampling Adequacy) ranged from 0 to 1 with criteria: (a) $M S A=1$, the variables can be predicted without error by other variables. MSA $>0,05$, the variables can still be predicted and can be used for further analysis. MSA $<0.5$, the variables cannot be predicted and cannot be analyzed further, or removed from other variables. Below is the result of the recapitulation of the MSA value which the value is above, 0.05 in overall, with the assumption that all variables are adequate for further analysis.

The method in producing the factors (factor extraction) used the Principal Component Analysis methods was shown in the Communalities table as the result of extraction. The greatest value on item 10 (A10): 0.658 it means approximately $65 \%$ variance of the variable on item 5 can be explained by the factors formed. The smallest percentage of variance was 0.201 on item 12 , or $20 \%$ variance of the variable of item 12 can be explained by the factor formed. And so on for other variables, with the requirement of the greater the communalities of a variable, means more closely related to the factors that are formed. 
The results of the analysis of the overall variance which can be explained by the components formed with the value of eigenvalues greater than 1.00 where there were 3 factors with the the value of eigenvalues greater than $(>) 1.00$. And 1 factor had the biggest value of the eigenvalues, that is factor 1 (1,992), which was then followed by factor 2 (1.498), factor 3 (1.703) so that cumulatively the 3 factors was 50,704 variance. The value of the first factor eigenvalues was the largest of which served as the proof of the dominant factor in all the variables / items present.

The result of the membership factor analysis by using Principal Component Analysis method with varimax with Kaiser Normalization rotation method, formed into three factors as listed in the table below: Based on the criteria, the factor membership of 2 (two) factors can be determined as written in table 4.11 .

Table 4. Factor and Loading Factor

\begin{tabular}{cccc}
\hline Factor & Member & Loading Factor & Number \\
\hline 1 & A8 & 0.697 & 4 \\
& A9 & 0.764 & \\
& A10 & 0.409 & \\
& A11 & $\mathbf{0 . 2 3 8}$ & \\
& A12 & 0.803 & 2 \\
\hline 3 & A7 & 0.598 & 2 \\
\hline
\end{tabular}

The table above shows that 8 items were constructed on the dimension of shalat, after the factor analysis was conducted it was formed into 3 factors, each factor was named as follows: The first factor with the number of 4 items was called the factor of importance of obligatory shalat, the second factor with the number of 2 items was named the 
factor of the importance of shalat sunna rawatib, and the third factor with the number of 2 items was named the factor of the importance of sunnah nawafil.

\section{Dimension of Zakat and Infak (Almsgiving)}

The calculation result of zakat and infak dimension factor analysis obtained by KMO was 0,615 classified as moderate, with chi-square value $=93.696$ with significance $(\mathrm{Sig}=0,000$ at dk: 28) showed that the value with significance level below 0,05 . This means that the correlation matrix formed is not the identity matrix so that all items variables in the analyzed religiosity instrument are adequate for further analysis.

Table 5. The Result of KMO Measure Sampling Adequacy and Bartlett Test of the Dimension of Zakat and Infaq

\begin{tabular}{cccc}
\hline \multirow{2}{*}{ KMO MSA } & \multicolumn{3}{c}{ Bartlett's Test of Sphericity } \\
\cline { 2 - 4 } & Approx. Chi-Square & df & Sig. \\
\hline 615 & 93.696 & 28 & 0.00 \\
\hline
\end{tabular}

In qakat and infak dimension there were 8 items, where all the items had shown value greater than $(>0.5)$. The significance criteria are: Sig. $>0.05$ then Ho is accepted. The value of Sig. $<0.05$ then Ho is rejected. The MSA (Measures of Sampling Adequacy) score ranges from 0 to 1 with the criteria: (a) MSA $=1$, the variable can be predicted without error by another variable. MSA $>0,05$, variable can still be predicted and can be analyzed further. MSA $<0.5$, variables cannot be predicted and cannot be analyzed further, or removed from other variables. Below is the result of the recapitulation of the overall MSA value in which the value is above 0.05 , with the assumption that all variables are adequate for further analysis.

The method in producing the factors (factor extraction) used was the Principal Component Analysis methods and were shown in the Communalities table as the result of 
extraction. The greates value was on item 10 (A10): 0.658 means that approximately $65 \%$ variance of item variable 5 can be explained by the factors formed. The smallest percentage of variance was 0.201 on item 12 , or $20 \%$ variance of the item variable 12 which can be explained by the factor formed. And so on for other variables, with the provision of the greater the communalities of a variable, means more closely related to the factors that are formed.

The results of the analysis of overall variance can be explained by the components formed with the value of eigenvalues greater than 1.00 where there were 3 factors with the greater eigenvalues $(>)$ of 1.00. And 1 factor had the greatest value of eigenvalues, which was factor 1 (1,918), which was then followed by factor 2 (1.422), factor 3 (1.012) so that cumulatively the 3 factors was 54,390 variance. The value of the first eigenvalues factor was the greatest that servedas a proof of the dominant factors in all the variables / items present.

The result of the membership factor analysis by using Principal Component Analysis method with varimax with Kaiser Normalization rotation method, formed into three factors as listed in the table below: Based on the criteria, the factor membership of 3 factors can be determined as written in following table.

Table 6. Factor dan Loading Factor

\begin{tabular}{cccc}
\hline Factor & Member & Loading Factor & Number \\
\hline 1 & A16 & 0.697 & 2 \\
& A21 & 0.764 & 3 \\
\hline 2 & A17 & 0.598 & \\
& A18 & 0.605 & 3 \\
& A19 & 0.590 & \\
\hline 3 & A20 & 0.501 & \\
& A22 & 0.604 & 0.778 \\
\end{tabular}


The table shows that 8 items were constructed on the dimensions of qakat and infak, after the factor analysis was conducted it was formed into 3 factors, each factor was named as follows: The first factor with the number of 2 items was named as the factor of the importance of understanding zakat, Second with the number of 3 items was named as the factor of the importance of understanding infak, and the third factor with the number of 3 items was named as the factor of paying rakat and infak.

\section{Dimension of Fasting}

The result of calculation of fasting dimension factor analysis obtained by KMO equal to: 0,629 classified as moderate, with the value of chi-square $=129.433$ with significance (Sig $=0,000$ at dk: 45) showed value with significance level below 0,05 . This means that the correlation matrix formed is not the identity matrix so that all items variables in the analyzed religiosity instrument are adequate for further analysis.

Table 7. The result of KMO Measure Sampling Adequacy and Bartlett Test of the Dimension of Fasting

\begin{tabular}{cccc}
\hline \multirow{2}{*}{ KMO MSA } & \multicolumn{3}{c}{ Bartlett's Test of Sphericity } \\
\cline { 2 - 4 } & Approx. Chi-Square & Df & Sig. \\
\hline 629 & 129.433 & 45 & .000 \\
\hline
\end{tabular}

The fasting dimension consisted of 10 items, in which items had shown greater value $(>0.5)$. The significance criteria are: Sig. $>0.05$ then Ho is accepted. The value of Sig. $<0.05$ then Ho is rejected. The MSA (Measures of Sampling Adequacy) score ranges from 0 to 1 with the criteria: (a) MSA $=1$, the variable can be predicted without error by another variable. MSA $>0,05$, variable can still be predicted and can be analyzed further. MSA $<0.5$, variables cannot be predicted and cannot be analyzed further, or removed from 
other variables. Below is the result of the recapitulation of the overall MSA value having the value above, 0.05, with the assumption that all variables are adequate for further analysis.

The method in producing the factors (factor extraction) used was Principal Component Analysis methods were shown in the Communalities table as the result of extraction. The greatest value was in item 25 (A25) : 0.699 means that about $69 \%$ variance from variable 25 can be explained by the factor formed. The smallest percentage of variance was 0.536 on item 33 , or $53, \%$ variance of item 33 the variable can be explained by the factor formed. And so on for other variables, with the provision of the greater the communalities of a variable, more closely related to the factors that are formed.

The result of the membership factor analysis by using Principal Component Analysis method with varimax with Kaiser Normalization rotation method, formed into 4 factors as shown in table below.

Table 8. Factor and Loading Factor

\begin{tabular}{cccc}
\hline Factor & Member & Loading Factor & Number \\
\hline 1 & A24 & 0.737 & 4 \\
& A26 & 0.530 & \\
& A27 & 0.462 & \\
& A29 & 0.696 & 3 \\
\hline 2 & A25 & 0.546 & \\
& A28 & 0.703 & 2 \\
& A30 & 0.734 & \\
\hline 3 & A31 & 0.919 & 1 \\
\hline
\end{tabular}

The table shows that 8 items were constructed in the fasting dimension, after the factor analysis was conducted 
then it was formed into 4 factors, each factor was named as follows: The first factor with the number of 4 items was named the factor of the importance of understanding fasting, the second factor with 3 items was named the factor of importance to understand the laws of fasting, the third factor with 2 items was named the factor of importance of compulsory fasting, and the fourth factor with 1 item was named the factor of importance to fulfill the sunnab fasting.

\section{Dimension of Reading the Qur'an}

The calculation result of KMO factor analysis of the dimension of reading the Qur'an obtained by KMO was: 0.578 classified as moderate, with chi-square value $=83.334$ with significance ( $\mathrm{Sig}=0,000$ at $\mathrm{dk}$ : 15 ) indicated the value with significance level below 0,05. This means that the correlation matrix formed was not the identity matrix so that items variables in the tazkiyatun nafs instrument analyzed are adequate for further analysis.

Table 9. The Result of KMO Measure Sampling Adequacy and Bartlett Test of the Dimension of Reading The Qur'an

\begin{tabular}{cccc}
\hline \multirow{2}{*}{ KMO MSA } & \multicolumn{3}{c}{ Bartlett's Test of Sphericity } \\
\cline { 2 - 4 } & Approx. Chi-Square & Df & Sig. \\
\hline 578 & 83.334 & 15 & .000 \\
\hline
\end{tabular}

In this dimension, there were 6 items, in which all items had shown greater value $(>0.5)$. The significance criteria were: Sig. $>0.05$ then $\mathrm{Ho}$ is accepted. The value of Sig. $<0.05$ then Ho is rejected. The MSA (Measures of Sampling Adequacy) score ranges from 0 to 1 with the criteria: (a) MSA $=1$, the variable can be predicted without error by another variable. MSA $>0,05$, variable can still be predicted and can be analyzed further. MSA $<0.5$, variables cannot be predicted and cannot be analyzed further or removed from other variables. 
The method in producing the factors (factor extraction) used was Principal Component Analysis methods and was shown in the Communalities table as the result of extraction. The greatest value was in item 39 (A39): 0.836 means that about $83 \%$ of the variance of variable item 5 can be explained by the factors formed. The smallest percentage of variance is 0.440 on item 38, or $38 \%$ variance of the item variable 38 can be explained by the factor formed. And so on for other variables, with the provision of the greater the communalities of a variable, means more closely related to the factors that are formed.

The result of the membership factor analysis by using Principal Component Analysis method with varimax with Kaiser Normalization rotation method, formed into 3 factors as shown in table below:

Table 10. Factor and Loading Factor

\begin{tabular}{cccc}
\hline Factor & Member & Loading Factor & Number \\
\hline 1 & A34 & 0.817 & 2 \\
& A35 & 0.851 & \\
\hline 2 & A36 & 0.682 & 3 \\
& A37 & 0.718 & \\
\hline 3 & A38 & 0.571 & 1 \\
\hline
\end{tabular}

The table above shows that 5 items were constructed in the dimension of reading the Qur'an, after the factor analysis was conducted it was formed into 3 factors, each factor was named as follows: The first factor with the number of 2 items was named the factor of the importance of reading the Qur'an, the second factor with the total of 3 items was named the factor of the capability in reading the Qur'an, and the third factor with the number of 1 item was named the factor of the importance of getting used to reading the Qur'an. 


\section{Relation Tazkiyyatun Nafs with Islamic Civilization}

Islam and civilization are indivisible unity. Since its emergence, Islam has brought the concept and the missions of civilization that are inherent in itself. ${ }^{35}$ Islam is recognized as both a religion and a civilization, ${ }^{36}$ because Islam is not only a religion but also a creator and living spirit of the great civilization of the world whose history spans over 14 centuries. In Nasr and Smith, "Islam is not only a religion; it is also the creator and living spirit of major world civilization with a long history stretching over fourteen centuries." This fact is acknowledged, for example, by the major contemporary orientalist Bernard Lewis's. He noted that Islam-the offspring of Arabia and the Arabian Prophetwas not only a system of belief and cult. It is a system of state, society, law, thought and art, a civilization with religion as its unifying eventually dominating, factor. ${ }^{37}$ Thus, Islam and civilization are indivisible unity.

Since its emergence, Islam has indeed brought the concepts and missions of civilization that is inherent in itself. Because Islam comes with a system that cobers the happiness of individuals and society (al-fard wa al-mujtama'), it is no wonder that Islamic civilization cannot be separated from its spirit, which is Islam. With Islam as din and madaniyyah, Muslim civilization becomes clear of its meaning, its concept, its characteristic, and its contribution to human and humanity. ${ }^{38}$

${ }^{35}$ Qosim Nurseha Dzulhadi, "Islam Sebagai Agama dan Peradaban", Jurnal Tsaqofah, Vol. 11, No. 1, Mei 2015, 151-168.

${ }^{36}$ Seyyed Hossein Nasr and Huston Smith, Islam: Religion, History, and Civilization, (Lahore-Pakistan: Suhail Academy, 2005), xi.

${ }^{37}$ Bernard Lewis, The Arab in History, (New York: Harper and Row Publisher, 1967), 113.

${ }^{38}$ Husein Mu'nis, al-Hadârab: Dirâsah fî̀ Usûl wa 'Awâmil Qiyâmihâ wa Tatawnurihâ, (Kuwait: 'Âlam al-Ma'rifah, 1978), 13. 
Islamic sciences are growing rapidly in line with the increasingly complex needs of the community in understanding religious guidance derived from the Qur'an and Hadith. Thus, the knowledge that is connected with the Qur'an, hadith, figh, kalam, tasawuf, and tarikh, is also developed. In addition, there is also a developing systematic knowledge and methodology in the study of the said fields. ${ }^{39}$ From generation to generation the spirit of developing science has been taking place. Research, experiments, inventions, and scientific methodologies are continuously carried out by Muslim intellectuals to this day.

The research of developing and testing the construct validity instrument of Taqkiyyatun Nafs, is part of the integration of science that combines the religious sciences as the subject of the material, which is then combined with exact science as a tool of analysis. These two integrations are carried out to: Firstly, to know the extent to which the concept of Tazkiyyatun Nafs can be formulated in accordance with the theories that have been initiated by the experts, as well as to serve as the initial hypothesis for the formation of a frame of thought. Second, the use of factor analysis as a mean to perform the construct validity analysis can provide information on whether a concept can be confirmed accurately through empirical testing in the field. Third, the result of the test has been declared as empirically valid, it is expected to be used as a measuring tool of one's personality, especially the one that is related to taubid (oneness of God), shalat (prayer), fasting, zakat and infak (almsgiving), and reading the Qur'an.

${ }^{39}$ Shobahussurur, "Lembaga Pendidikan dalam Khazanah Klasik: Telaah Proses Sejarah dan Transimi Ilmu Pengetahuan", Jurnal Tsaqofah, Vol. 11, No. 1, Mei 2015, 89-112. 


\section{Conclusion}

Based on the results of the research on the developing and testing the construct validity instrument of Tazkiyyatun Nafs, it can be concluded that: First, factor extractation and rotation by using confirmatory method at the empirical stage had confirmed 15 factors, with $\mathrm{KMO}$ values of all dimensions above $>0.50$, : Dimension of reading the Qur'an with $\mathrm{KMO}$ value of 0.578 , fasting dimension with $\mathrm{KMO}$ value of 0,629 , rakat and infak dimension with $\mathrm{KMO}$ value of 0,615 , dimension of shalat with KMO value of 0,660 , and dimension of taubid with KMO value of 0,558 .

Further, the assessment of the MSA (measure of sampling adequacy) value in the anti-image correlation table was performed to identify that the sampling had been sufficiently qualified to be carried on to the factor analysis with the MSA value $>0.3$, assuming that the MSA value below $<0.3$ must be eliminated. The result of construct validity by using factor analysis has proved that the number of items that had been estimated were 37 indicators that were $>0.30$, out of 39 items, while three indicators were $<0.30$ which then eliminated. The two items that were eliminated were item A4 on the dimension of taubid, and item A11 on the dimension of shalat. 


\section{REFERENCES}

Azwar, Saifuddin. Dasar-dasar Psikometri. Yogyakarta: Pustaka Pelajar, 2005.

- Validitas dan Reliabilitas. Yogyakarta: Pustaka Pelajar, 2012.

Camic, Paul M. Qualitative Research in Psychology Expanding Perspective and Design. Washington, DC: American Psychology Association, 2003.

Colton, David. and Robert W. Covert, Designing and Constructing Instruments for Social Research and Evaluation. San Francisco: Jossey-Basse, 2007.

Darazat, Zakiah. Ilmu Pendidikan Islam. Jakarta: Bumi Aksara, Jakarta: 2009.

Dzulhadi, Qosim Nurseha. "Islam Sebagai Agama dan Peradaban”, Jurnal Tsaqofah, Vol. 11, No. 1, Mei 2015.

Firdaos, Rijal. "Metode Pengembangan Instrumen Pengukur Kecerdasan Spiritual Mahasiswa", Jurnal Edukasia, Vol. 11, No. 2, August 2016.

- "Studi Analisis Faktor Konfimatori terhadap Dimensi Sikap Keberagamaan Mahasiswa", Jurnal Inferensi, Vol. 10, No. 2, December 2016.

- Desain Instrumen Pengukur Afektif. Lampung: AURA Publishing, 2016.

Gable, Robert K. Instrument Development in The Affective Domain. Buston: Kluwer-Nijhoff Publishing, 1986.

al-Ghazali. Mu'raj al-Salikin, tranls. Fathur Rahman. Yogyakarta: Mitra Pustaka, 2005.

Harrington, Donna. Confirmatory Factor Analysis. USA: Oxford Universty Press, 2009. 
Hasbullah. Dasar-dasar Ilmu Pendidikan. Jakarta: Raja Grafindo Persada, 2005.

Husein, Mu'nis. al-Hadarah: Dirasah fi Ushul wa 'Awamil Qiyamiha wa Tatawwuriha. Kuwait: 'Âlam al-Ma'rifah, 1978.

Ihsan, Fuad. Dasar-dasar Kependidikan. Jakarta: Rineka Cipta, 2008.

Jumantoro, Totok. Kamus Ilmu Taswuf. Jakarta: Amzah, 2005.

Kerlinger, Fred N. Asas-asas Penelitian Behavioral, transl. Landung N. Simatupang. Yogyakarta: UGM Press, 2004.

Kothari, C.R. Research Methodology. New Delhi: New Age International Publisher, 2004.

Lewis, Bernad. The Arab in History. New York: Harper and Row Publisher, 1967.

Nasr, Seyyed Hossein and Huston Smith. Islam: Religion, History, and Civilization. Lahore-Pakistan: Suhail Academy, 2005.

Purwanto. Metodologi Penelitian Kuantitatif. Yogyakarta: Pustaka Pelajar, 2010.

Riduan. Pengantar Statistik. Bandung: Alafabeta, 2009.

Ridwan, Kafrawi. Ensiklopedi Islam. Jakarta: Ichtiar Baru, 1994.

Richey, Rita C. and James D. Klien. Design and Development Research: Methodes, Strategies, and Issues. New Jersey: Lawrence Erlbaum, 2007.

Robinson, Kurpius and E. Sharon. Testing and Measurement. California: SAGE Publication, 2006.

Semiawan, Conny R. Catatan Kecil Tentang Penelitian dan Pengembangan Ilmu Pengetahuan Jakarta: Kencana Prenada Media Group, 2008. 
Shaleh, Moh. Bertobat Sambil Berobat. Jakarta: Mizan Publika, 2008.

Shalihin, M. Tazkiyatun Nafs dalam Perspektif Tasawuf alGhazali. Bandung: Pustaka Setia, 2000.

Shobahussurur, "Lembaga Pendidikan dalam Khazanah Klasik: Telaah Proses Sejarah dan Transimi Ilmu Pengetahuan", Jurnal Tsaqofah, Vol. 11, No. 1, Mei 2015.

Sudjana, Nana. Penilaian Hasil Proses Belajar Mengajar. Bandung: Remaja Rosdakarya, 2005.

Tafsir, Ahmad. Pendidikan Agama dalam Keluarga. Bandung: Remaja Rosdakarya, 2002.

Taufiq, Muhammad Izzadudin. Panduan Lengkap dan Praktis Psikologi Islam. Jakarta: Gema Insani, 2006.

Zubaedi. Design Pendidikan Karakter. Jakarta: Prenada Media Group, 2011.

Suryabrata, Sumadi. Alat Ukur Psikologis.Yogyakarta: Andi, 2005. 
Rijal Firdaos 